\title{
The Smart Growth of Ulanhot and Arlington
}

\author{
Shouqiang Li \\ School of North China Electric Power University, Baoding 071003, China \\ adianjiweiling@foxmail.com
}

Keywords: Smart Growth, Developing Plan, Ulanhot, Arlington.

\begin{abstract}
The paper analyze the smart growth of ulanhot and Arlington. Because Alington has been successful in smart growth, it can provide rich experience to Ulanhot, which needs smart growth policies at present. We analyze the detailed situation of Arlington and Ulanhot. According to the current plan of Arlington, we made a series of new plans for Ulanhot to help it develop rapidly and smartly.
\end{abstract}

\section{Introduction}

Nowadays, the level of urbanization is getting higher and higher, and more and more people are moving to the city at the same time. It is projected that by 2050, 66 percent of the world's population will be urban - that will result in a projected 2.5 billion people being added to the urban population. [1] In other words, the progress of the city is related to the life' improvement of most people of the world. After a long period of development, now Smart Growth has become a complete system of urban development. There are many cities in the world that adhere to the principle of Smart Growth, while there are also a lot of cities that deviate from the principle of Smart Growth, are facing many problems. We need to study the strength of good example, reveal the shortcoming of the bad examples, judge whether a city confirms with smart growth or not, and put forward suitable development plans for the city.

Growth presents a tremendous opportunity for progress. And in many communities where development has improved daily life, the economy, and the environment, smart growth principle has been the key to that success.

The paper considers 6 aspects: growth patterns and trends, natural resources and environmental quality, transportation, affordable housing, finance, the leadership of the survey, which includes 16 indexes: growth of population; population density; variation of population distribution; growth of employment; variation of conservation area; variation of agricultural land ;variation of bus share; variation of bike/walk share; the growth rate of congestion; affording house; growth of total income; the ratio of income and expenditure; foresight of decisions; fairness of decisions and public participation. The paper analyze the smart growth of ulanhot and Arlington. Because Alington has been successful in smart growth, it can provide rich experience to Ulanhot, which needs smart growth policies at present.

\section{Situation of Ulanhot and Arlington}

\subsection{Basic situation}

Arlington County is a county in the Commonwealth of Virginia, east of America. Total area is 26 acre. In 2015, the county's population was estimate at 229,164, density is 8,814 per acre. In early 2002, Arlington has access to EPA "smart growth state Achievement Award", "smart growth overall excellence" and other honors, is a typical case of smart growth.

Located in eastern Inner Mongolia Autonomous Region and hinterland of Horqin grassland, Ulanhot is a total area of 2,353.5 acre. Most of the area is forest, grassland, wetlands, lakes. It includes 740,000 acres of arable land, 2,120,000 acres of grassland, and 840,000 acres of forest and so on. During the development, however, there are a series of problems in Ulanhot, for example, Built-up area expanded rapidly, and resources and agricultural land area reduce rapidly. The severe urban 
sprawl deviates from the Smart Growth strategy. The process of developing urban traffic, the improvement of public transport system is ignored. At the end of 2010, the proportion of bus travel was about $15 \%$, and showed a decreasing trend. The rapid increase of motor vehicles, especially private cars, will lead to environmental pollution, accelerate traffic congestion. It does not meet the Smart Growth strategy. Compared to the disposable income of residents, housing prices are relatively high, so some residents cannot afford housing. At present, the public can seldom participate in most of the development decision making. Even if the public participate, developers rarely adopted considering their own interests. This eliminates the enthusiasm of public participation. It is not conducive to the city's smart growth.

\subsection{Detailed Comparison.}

Detailed data found from official database [2] [3] are listed in table 1.

Table 1. Detailed comparison of Ulanhot and Arlington

\begin{tabular}{|c|c|c|c|c|}
\hline \multirow[t]{2}{*}{ City } & \multicolumn{2}{|c|}{ Ulanhot } & \multicolumn{2}{|c|}{ Arlington } \\
\hline & situation & Grade & situation & Grade \\
\hline $\begin{array}{l}\text { Growth of population } \\
(\%)\end{array}$ & 1.22 & 3 & 1.66 & 4 \\
\hline $\begin{array}{l}\text { Population density } \\
\text { (person /kilometer) }\end{array}$ & 378 & 1 & 3324 & 3 \\
\hline Variation of population distribution & 0.7 & 4 & 0.8 & 5 \\
\hline $\begin{array}{c}\text { Growth of employment } \\
(\%)\end{array}$ & 3.6 & 5 & 2.13 & 2 \\
\hline $\begin{array}{l}\text { Variation of conservation } \\
\text { area(acre/person) }\end{array}$ & -1.4 & 1 & -0.65 & 3 \\
\hline $\begin{array}{c}\text { Variation of agricultural land (acre per } \\
\text { person) }\end{array}$ & -1.2 & 1 & -0.04 & 5 \\
\hline $\begin{array}{c}\text { Variation of bus share } \\
(\%)\end{array}$ & -1.5 & 2 & 2.7 & 5 \\
\hline Variation of bike/walk share (\%) & -2.8 & 1 & -1.9 & 2 \\
\hline The growth rate of congestion & Fast & 2 & Slow & 4 \\
\hline $\begin{array}{l}\text { Affording house } \\
\qquad(\%)\end{array}$ & $26 \sim 35$ & 1 & 98 & 3 \\
\hline $\begin{array}{c}\text { Growth of total income } \\
(\%)\end{array}$ & $9.4 \%$ & 4 & $6.8 \%$ & 3 \\
\hline The ratio of income and expenditure & 0.79 & 3 & 1.15 & 4 \\
\hline Foresight of decisions & Good & 3 & Good & 3 \\
\hline Fairness of decisions & General & 2 & Good & 3 \\
\hline Public participation & General & 2 & General & 2 \\
\hline
\end{tabular}

\section{Current plan for Arlington}

Arlington has implemented smart growth plan for many years, and has achieved great results. Now, it has become a model for other city whose goal is smart growth, provided a lot of reference to them. Transit investments can be used as a catalyst to reshape communities; Multimodal transportation strategies can result in substantial benefits -allowing continued growth with less reliance on autos; Establish the vision, design supportive public; policies/plans and tools and be patient; Build community consensus; Ensure that transit is integrated with development - not secondary; An attractive and functional pedestrian environment is important; Develop public-private partnerships to continue consensus building and assist in the implementation; Integrity of plan - be consistent; Do the detailed planning at the sector area to avoid the battles at development review time; Station areas must be able to satisfy the daily needs of users if they are to really to leave their cars behind (mixed use); Reduce parking requirements. 


\section{New Plan for Ulanhot}

In order to protect the natural resources, it is necessary to promote the use of science and technology to improve the yield per unit of arable land, develop nomadic industry rational, and stop the severe resource land losing caused by overgrazing and over reclamation. And it is also necessary to develop tourism rationally, strengthen the protection of natural scenic spots, and keep local features.

The goal is to increase land use efficiency, compact layout building. Through TOD (Traffic Oriented Development) [4], it is wise to advocate for initiative ting in the original community, against the occupation of agricultural land, control built-up area, slow down the spread of the city. By using of inefficient land, we can build high density residential, commercial, office and other mixed areas from the home to the bus station, to provide a wide range of walking area to residents and opportunity to public transport

In order to develop high efficiency and quality bus city, it is necessary to pay attention to the construction of public transport, improve the adaptability crowds, reading, period and fare. At the same time, it is possible to accomplish the intensive development of urban land under the guidance of public transport.

The government should promote the construction of affordable house, provide multi-type, multilocation house options, so that different income families can choose housing units and location according to their own economic capacity. In addition, the government can provide housing subsidies, so it is easier for resident to buy their own house. And the construction of walking community can reduce the traveling distance and cost, reduce the cost of living for low-income people.

As an investment opportunity, Smart Growth can provide a variety of investment projects, including Brownfield, Grey field, urban infill, transit oriented projects, traditional neighborhood development on Greenfield sites. It will increase the government total expenditure and total revenue. At the same time, it will provide a large number of jobs, improve per capita disposable income as well as the affordable housing index

\section{References}

[1]. World Urbanization Prospects United Nations. 2014. https://esa.un.org/unpd/wup/Publications/Files/WUP2014-Highlights.pdf

[2]. EPA, “This is Smart Growth.” 2016 https://www.epa.gov/smartgrowth/smart-growth-publication

[3]. EPA, "Smart Growth: A Guide to Developing and Implementing Greenhouse Gas Reductions Programs."

[4]. Canfei, Zou Peisi, Yin Wei. Smart growth policy evaluation (translation) [J]. Xinjiang agricultural science, 2011 (7): 1371-1371. 